\title{
MILBEMYCINS, A NEW FAMILY OF MACROLIDE ANTIBIOTICS \\ FERMENTATION, ISOLATION, PHYSICO-CHEMICAL PROPERTIES AND BIOCONVERSION OF MILBEMYCINS J AND K
}

\author{
Michinisa Ono, Hiroshi Mishima*, Yo Takiguchi* \\ and Michiya Terao \\ Fermentation Research Laboratories, Sankyo Co., Ltd. \\ 1-12-1, Shibakubo, Tanashi, Tokyo 188, Japan
}

(Received for publication November 18, 1982)

\begin{abstract}
Strain Rf-107, a mutant of Streptomyces hygroscopicus subsp. aureolacrimosus, obtained with ultraviolet irradiation, produced two new macrolide antibiotics, milbemycins $\mathrm{J}$ and $\mathrm{K}$ without production of any of the other milbemycins described in the previous paper. Fermentation studies on the strain were conducted in shake flasks and 30-liter jar fermentors. Isolation of the antibiotics was performed by adsorption on resinous adsorbent followed by elution with aqueous $\mathrm{MeOH}$. Purification of milbemycins $\mathrm{J}$ and $\mathrm{K}$ was completed with Lobar Si 60 column chromatography to give colorless crystals. Physico-chemical data, such as UV, IR and NMR spectra are described. Milbemycins $\mathrm{J}$ and $\mathrm{K}$ were readily converted by the intact cells of the parent strain to milbemycins $\alpha_{1}$ and $\alpha_{3}$, respectively. Physico-chemical characterization and the bioconversion studies revealed that milbemycins $\mathrm{J}$ and $\mathrm{K}$ were new antibiotics having the 16-membered macrocyclic lactone with a 6,6-membered spiroketal ring system.
\end{abstract}

Streptomyces hygroscopicus subsp. aureolacrimosus produced 13 milbemycins with insecticidal and acaricidal activity ${ }^{1)}$; all the milbemycins have the 16 -membered macrolide structure ${ }^{2,3)}$. It was also reported that the strain produced five new milbemycins $\mathrm{D}, \mathrm{E}, \mathrm{F}, \mathrm{G}$ and $\mathrm{H}^{4)}$.

We isolated some mutants of the organism by means of treatment with $N$-methyl- $N^{\prime}$-nitro- $N$ nitrosoguanidine (NTG) and ultraviolet (UV) irradiation. One of these mutants, strain Rf-1074), produced two new milbemycins $\mathrm{J}$ and $\mathrm{K}$ without production of any other known milbemycins.

In this paper, we describe the fermentation, isolation, physico-chemical properties and bioconversion of milbemycins $\mathrm{J}$ and $\mathrm{K}$. Biological properties and structure elucidation of the antibiotics will be reported elsewhere.

\section{Materials and Methods}

\section{Microorganism}

The strain Rf-107 and the parent strain were maintained on YM slant agar.

Fermentation

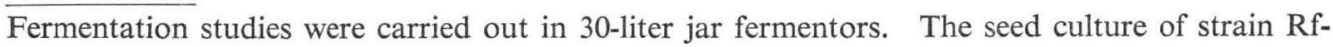
107 was prepared by cultivation at $28^{\circ} \mathrm{C}$ for 2 days on a rotary shaker $(220 \mathrm{rpm}, 7 \mathrm{~cm})$ in a 2-liter Erlenmeyer flask containing $500 \mathrm{ml}$ of a medium with the following composition: $1 \%$ sucrose, $0.35 \%$ Polypepton and $0.05 \% \mathrm{~K}_{2} \mathrm{HPO}_{4}$. One liter of a good preculture was then inoculated into a 30-liter jar fermentor containing 20 liters of a fermentation medium (BM-2) with the following composition: $6 \%$ glucose, $1 \%$ soybean meal, $1 \%$ skim milk, $0.5 \%$ corn starch and $0.05 \% \mathrm{CaCO}_{3}$. The $\mathrm{pH}$ of the $\mathrm{BM}-2$ medium was adjusted to 7.2 before sterilizing at $120^{\circ} \mathrm{C}$ for 25 minutes. Fermentation was carried out under the fol-

\footnotetext{
* Present address: 2-58 1-Chome, Hiromachi, Shinagawa-ku, Tokyo 140, Japan
} 
lowing condition: temperature $28^{\circ} \mathrm{C}$, aeration 10 liters/minute, agitation $150 \sim 250 \mathrm{rpm}$ and internal pressure $0.5 \mathrm{~kg} / \mathrm{cm}^{2}$.

Isolation

The extraction, isolation and purification procedures of milbemycins $\mathbf{J}$ and $\mathbf{K}$ were almost identical to those mentioned in the previous paper ${ }^{1,5)}$. Adsorbent resin HP-10 and Lobar column Si 60 for chromatography were purchased from Mitsubishi-Kasei Co., Ltd. and E. Merck Co., Ltd., respectively.

Fermentation broth (30 liters) containing milbemycins $\mathbf{J}$ and $\mathbf{K}$ was adjusted to $\mathrm{pH} 3.0$ and filtered with Celite. The cake $(5 \mathrm{~kg})$ was extracted twice with 10 liters of $\mathrm{MeOH}$; to 20 liters of the extract, 20 liters of water was added. The resulting aqueous $\mathrm{MeOH}$ was extracted with 50 liters of $n$-hexane. The $n$-hexane was evaporated under reduced pressure to obtain the residue, which was dissolved in $500 \mathrm{ml}$ of $\mathrm{MeOH}$. To this solution $500 \mathrm{ml}$ of water was added. This solution was applied to 1 liter of Diaion HP10 column. The adsorbate was washed with 2 liters of $60 \%$ aqueous $\mathrm{MeOH}$, and eluted with 1 liter of $95 \%$ aqueous $\mathrm{MeOH}$. Fractions containing milbemycins were collected and $800 \mathrm{ml}$ of water was added to 1 liter of the fractions. The approximately $50 \%$ aqueous $\mathrm{MeOH}$ solution was extracted with 2 liters of $n$-hexane. The extracts were evaporated under reduced pressure to obtain $18 \mathrm{~g}$ of oily substance. The residue was dissolved in $20 \mathrm{ml}$ of $n$-hexane and then applied to a Lobar column Si 60 . The column was eluted with a mixture of $n$-hexane and ethyl acetate $(8: 2)$. The fractions containing milbemycins $\mathrm{J}$ and $\mathrm{K}$ were pooled separately on the basis of TLC analysis ${ }^{1)}$ and the solvent was removed under reduced pressure. The solid thus obtained was recrystallized from a mixture of $n$-hexane and chloroform $(5: 1)$ to yield milbemycin $\mathbf{J}(1.8 \mathrm{~g})$ as colorless crystals. Colorless crystals $(1.1 \mathrm{~g})$ of milbemycin $\mathrm{K}$ were obtained after recrystallization from $n$-hexane.

Bioconversion

A spore suspension $(1 \mathrm{ml})$ of $S$. hygroscopicus subsp. aureolacrimosus parent strain was inoculated into a $500-\mathrm{ml}$ Erlenmeyer flask containing $100 \mathrm{ml}$ of seed medium consisting of $1 \%$ sucrose, $0.35 \%$ Polypepton and $0.05 \% \mathrm{~K}_{2} \mathrm{HPO}_{4}$. The inoculum was incubated at $28^{\circ} \mathrm{C}$ for 48 hours on a rotary shaker $(220 \mathrm{rpm}, 7 \mathrm{~cm})$. Five milliliters of the culture broth thus obtained were transferred into a $500-\mathrm{ml}$ Erlenmeyer flask containing $100 \mathrm{ml}$ of the medium consisting of $6 \%$ glucose, $0.2 \%$ meat extract, $0.2 \%$ corn steep liquor, $0.3 \%$ Polypepton, $0.5 \%$ skim milk, $0.05 \% \mathrm{MgSO}_{4} \cdot 7 \mathrm{H}_{2} \mathrm{O}$ and $0.05 \% \mathrm{CaCO}_{3}(\mathrm{pH} 7.2$ before sterilization). After incubation of the flasks on the rotary shaker at $28^{\circ} \mathrm{C}$ for 48 hours, cells were harvested from $50 \mathrm{ml}$ of the culture broth by centrifugation at $600 \times g$ for 10 minutes, washed twice with $50 \mathrm{ml}$ of sterile saline, and then employed in the bioconversion as intact cells. For the preparation of the cell free extracts, $20 \%$ (wt/vol) suspension of washed cells in $0.1 \mathrm{M}$ phosphate buffer $(\mathrm{pH} 7.0)$ were cooled in an ice water bath, and disrupted for 10 minutes with an ultrasonic disintegrator (Branson Sonifier model 200) maintaining the suspension below $4^{\circ} \mathrm{C}$. The homogenate was subjected to centrifugation at $18,000 \times g$ for 30 minutes at $4^{\circ} \mathrm{C}$. Milbemycins $\mathrm{J}, \mathrm{K}, \alpha_{1}$ and $\alpha_{3}$ in the reaction mixture were monitored by TLC and HPLC ${ }^{5)}$.

\section{Results and Discussion}

\section{Fermentation}

Fermentation studies on strain Rf-107 were conducted in 30-liter jar fermentors containing 20 liters of the BM-2 medium. Typical tropophase-idiophase kinetics were exhibited (Fig. 1). The packed cell volume in the culture broth increased in the first 3 days and remained constant thereafter. The antibiotics were first detected in the broth after 5 days cultivation and increased at a linear rate for the next 5 days. The yields of milbemycins $\mathrm{J}$ and $\mathrm{K}$ reached $300 \mu \mathrm{g} / \mathrm{ml}$ and $270 \mu \mathrm{g} / \mathrm{ml}$ at 12 days cultivation, respectively. The HPLC pattern of the culture broth after 12 days cultivation showed that strain Rf107 produced two new milbemycins $\mathrm{J}$ and $\mathrm{K}$ as major products and some minor components without production of any other known milbemycins. The results described above suggest that strain Rf-107 was blocked in the biosynthetic pathway of milbemycins which were produced by the parent strain and strain Au-3. 
Fig. 1. Time course of milbemycins $\mathbf{J}$ and $\mathbf{K}$ production by strain Rf-107 in a 30-liter jar fermentor.

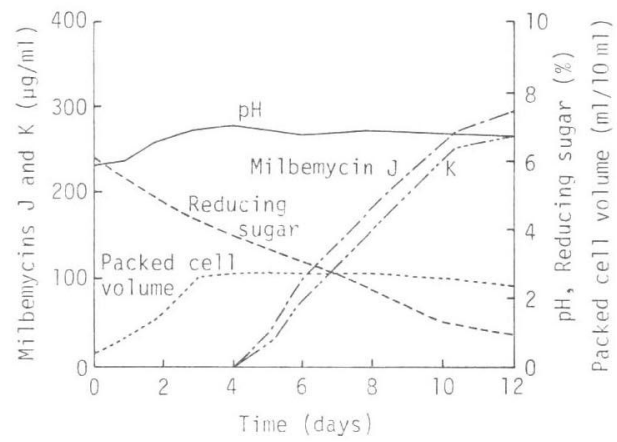

Fig. 3. Isolation and separation of milbemycins $\mathbf{J}$ and $\mathrm{K}$.

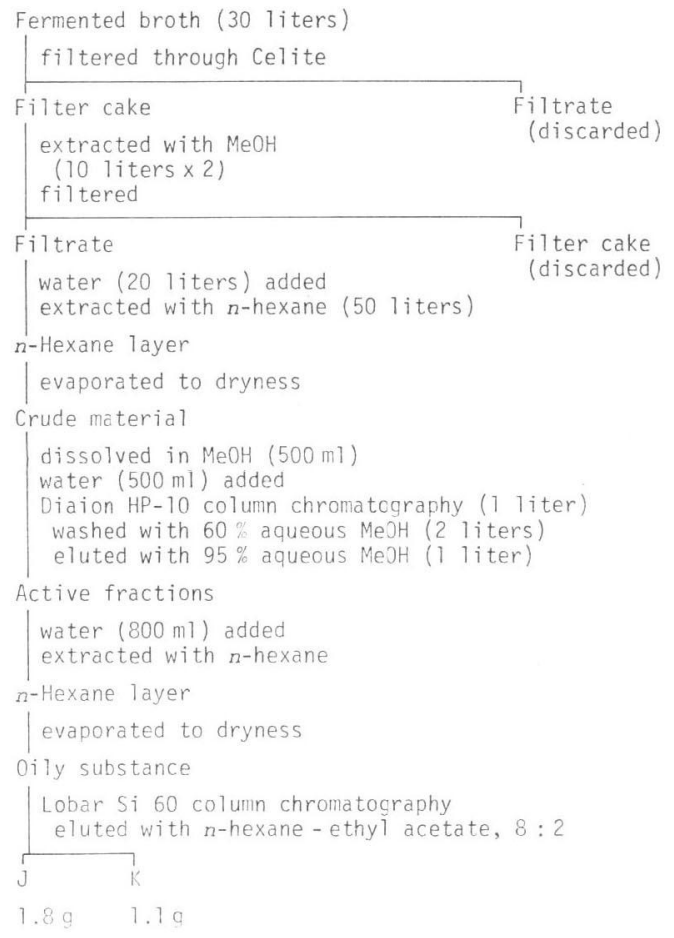

Fig. 2. HPLC pattern of 12-day culture broth of strain Rf-107.

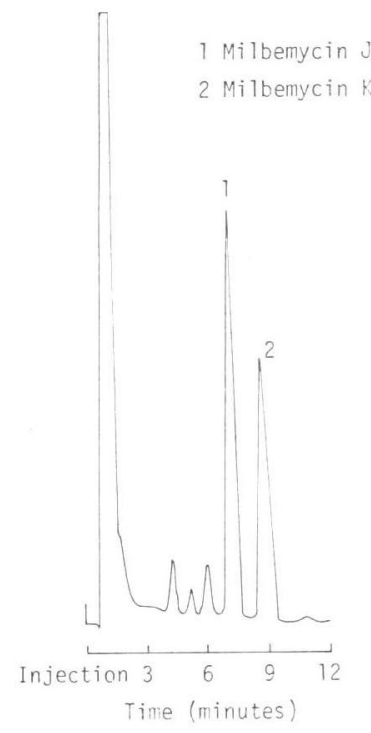

Fig. 4. UV absorption spectra of milbemycins J and $\mathrm{K}$ in ethanol.

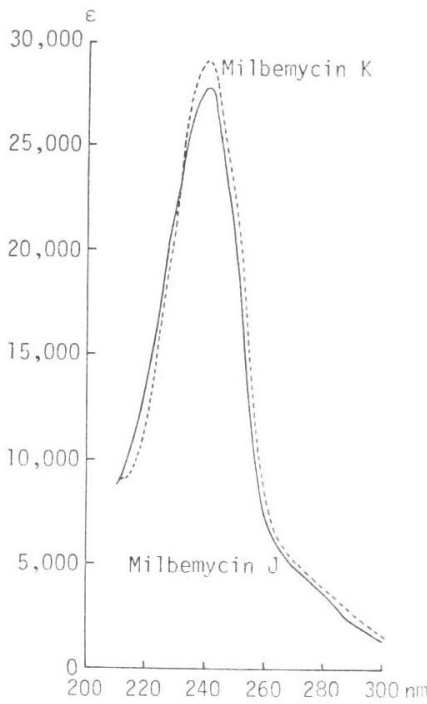

Isolation

The isolation and separation procedure of milbemycins $\mathrm{J}$ and $\mathrm{K}$ is outlined in Fig. 3. Milbemycins $\mathrm{J}$ and $\mathrm{K}$ were obtained as colorless crystals after recrystallization from a mixture of $n$-hexane - chloroform (5:1) and $n$-hexane, respectively.

\section{Physico-chemical Properties}

Physico-chemical data of milbemycins $\mathbf{J}$ and $\mathrm{K}$ are listed in Table 1. Milbemycins $\mathbf{J}$ and $\mathrm{K}$ are easily soluble in $n$-hexane, benzene, chloroform and acetone, soluble in $\mathrm{MeOH}$ and EtOH but insoluble 
Table 1. Physico-chemical properties of milbemycins $\mathrm{J}$ and $\mathrm{K}$.

\begin{tabular}{l|l|l}
\hline \multicolumn{1}{c|}{ Milbemycin } & \multicolumn{1}{|c}{$\mathrm{J}$} & \multicolumn{1}{c}{$\mathrm{K}$} \\
\hline Nature & $\begin{array}{c}\text { Colorless } \\
\text { crystals } \\
\text { mp }\left({ }^{\circ} \mathrm{C}\right)\end{array}$ & $\begin{array}{c}\text { Colorless } \\
\text { crystals }\end{array}$ \\
Mol. Form. & $213 \sim 215$ & $215 \sim 218$ \\
$\mathrm{M} . \mathrm{W}$. (mass) & $\mathrm{C}_{31} \mathrm{H}_{42} \mathrm{O}_{7}$ & $\mathrm{C}_{32} \mathrm{H}_{44} \mathrm{O}_{7}$ \\
$\mathrm{UV} \lambda_{\max }^{\mathrm{EtOH}} \mathrm{nm}(\varepsilon)$ & $240(28000)$ & 540 \\
{$[\alpha]_{\mathrm{D}}^{27 *}$} & +40 & $240(29200)$ \\
$\mathrm{Rf}^{* *}$ & 0.67 & +42 \\
\hline
\end{tabular}

* c 0.25, acetone.

** Silica gel $60 \mathrm{~F}-254$ plates (Merck), developed in dioxane $-\mathrm{CCl}_{4}, 15: 85$. in water. The UV absorption spectra of milbemycins $\mathrm{J}$ and $\mathrm{K}$ showed a single maximum at $240 \mathrm{~nm}$ ( $\varepsilon 28000$ and 29200), wihch is ascribed to a conjugated diene system and/or an $\alpha, \beta$ unsaturated ketone (Fig. 4). In IR spectra of milbemycins $\mathrm{J}$ and $\mathrm{K}$, absorption bands at 3510 , 1730 and $1680 \mathrm{~cm}^{-1}$ were assigned to tertiary hydroxyl, 16-membered lactone and $\alpha, \beta$-unsaturated carbonyl groups, respectively (Fig. 5). An olefinic proton signal at $5.41 \mathrm{ppm}$ in the ${ }^{1} \mathrm{H}$ NMR spectra of milbemycin $\alpha_{1}$ or $\alpha_{3}$ at C-3 position shifted to a low field at $6.54 \mathrm{ppm}$ in those

Fig. 5-a. IR spectrum of milbemycin J (Nujol).

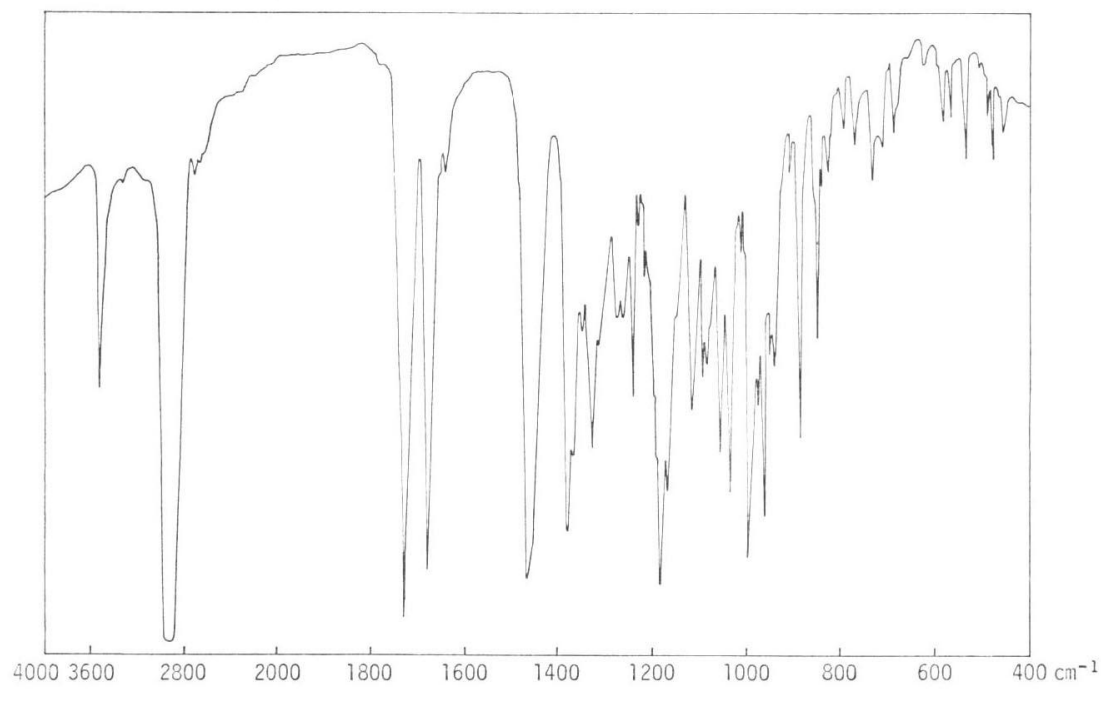

Fig. 5-b. IR spectrum of milbemycin K (Nujol).

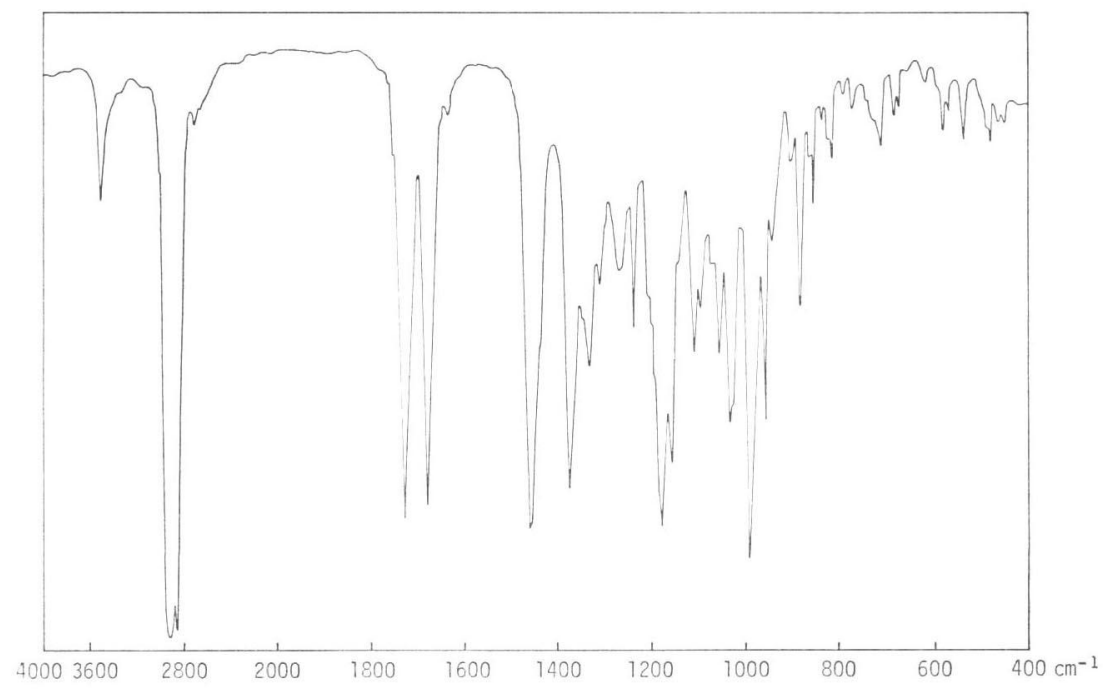


Fig. 6-a. $\quad{ }^{1} \mathrm{H}$ NMR spectrum of milbemycin $\mathbf{J}\left(\mathrm{CDCl}_{3}\right)$.

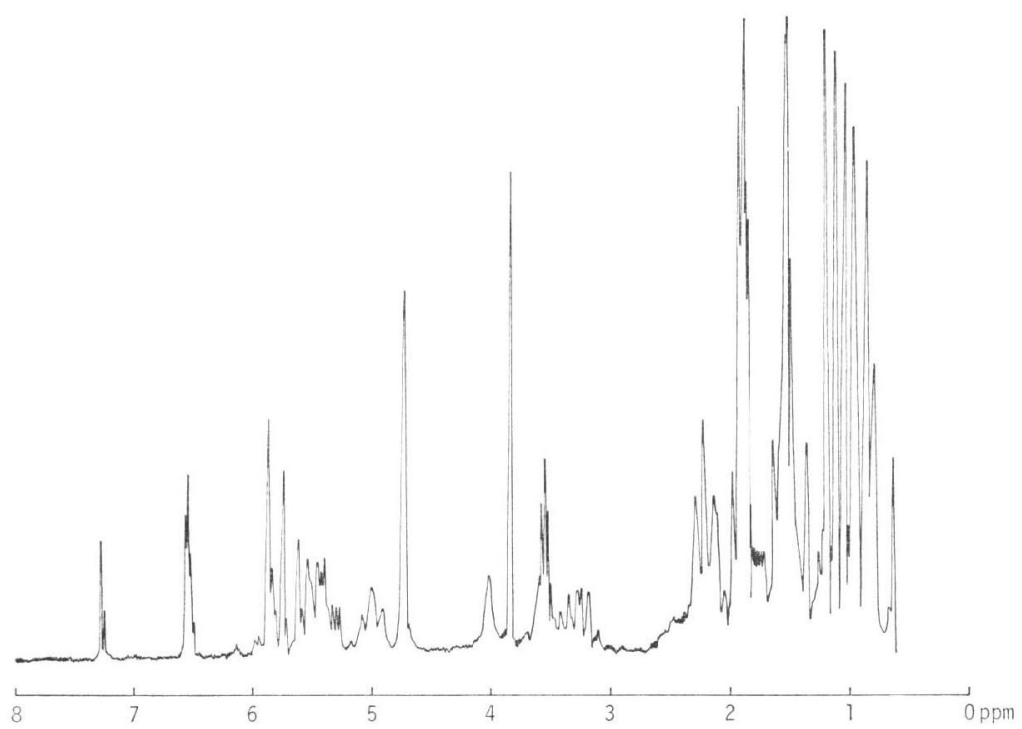

Fig. 6-b. ${ }^{1} \mathrm{H}$ NMR spectrum of milbemycin $\mathrm{K}\left(\mathrm{CDCl}_{3}\right)$.

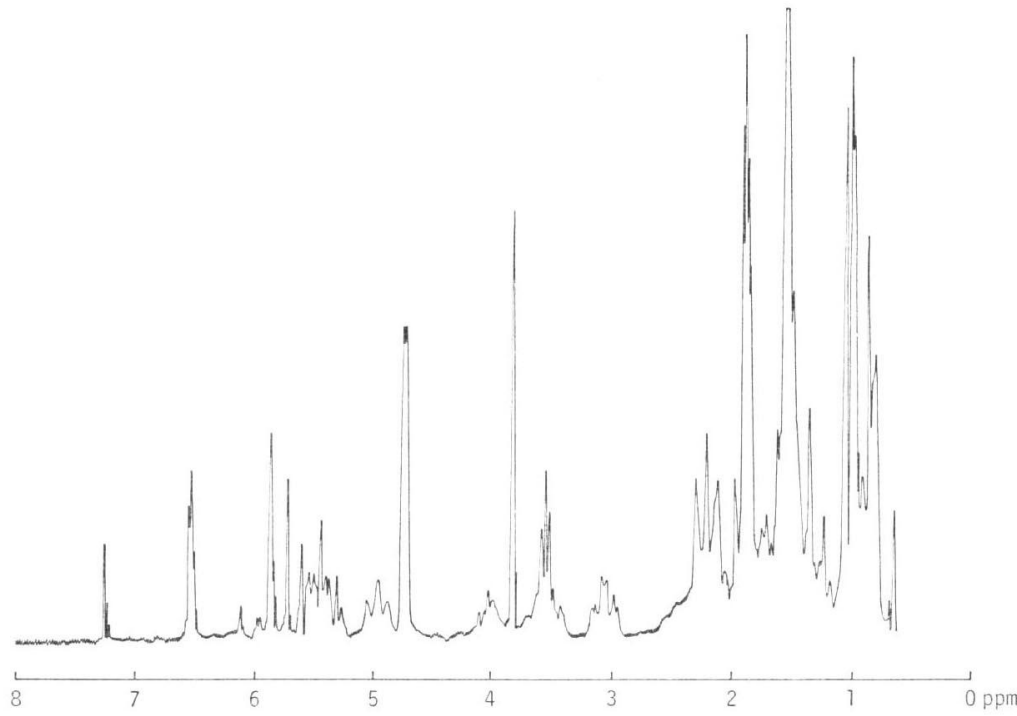

of milbemycins $\mathbf{J}$ and $\mathrm{K}$ (Fig. 6). The mass spectra of milbemycins $\mathbf{J}$ and $\mathrm{K}$ showed a molecular ion peak $\left(m / z \mathrm{M}^{+}: 526\right)$ and $\left(m / z \mathrm{M}^{+}: 540\right)$, respectively. The physico-chemical properties described above revealed that milbemycins $\mathrm{J}$ and $\mathrm{K}$ are two new macrolides possessing 16 -membered macrocyclic lactone structure with cyclohexenone as shown in following paper.

Bioconversion of Milbemycins $\mathrm{J}$ and $\mathrm{K}$

To study the structure relationship between milbemycins $\mathrm{J}$ and $\mathrm{K}$, and other milbemycins, the bioconversion studies were carried out using intact cells and cell free extracts of the parent strain. It was confirmed that milbemycins $\mathrm{J}$ and $\mathrm{K}$ were converted by the intact cells of the parent strain to milbemycins 
Fig. 7. HPLC pattern of the reaction mixture for the bioconversion of milbemycins $\mathrm{J}$ and $\mathrm{K}$ by the intact cells.

Milbemycins $\mathbf{J}$ and $\mathrm{K}$ were dissolved in $\left(\mathrm{CH}_{3}\right)_{2}$ SO and added to the reaction mixture, which contained 0.64 mmole of milbemycin $\mathbf{J}$ or 0.22 mmole of milbemycin $\mathrm{K}$ and $11 \mathrm{mg}$ (dry weight) of washed cells in a total volume of $1 \mathrm{ml}$ of $0.1 \mathrm{~m}$ phosphate buffer ( $\mathrm{pH} 7.0$ ). Incubation was carried out at $28^{\circ} \mathrm{C}$ with shaking. The reaction mixture was mixed with $3 \mathrm{ml}$ of acetone and shaken for about 2 minutes. The mixture was centrifuged at $3,000 \mathrm{rpm}$ for 5 minutes and $10 \mu \mathrm{l}$ of the supernatant solution was injected into the HPLC.
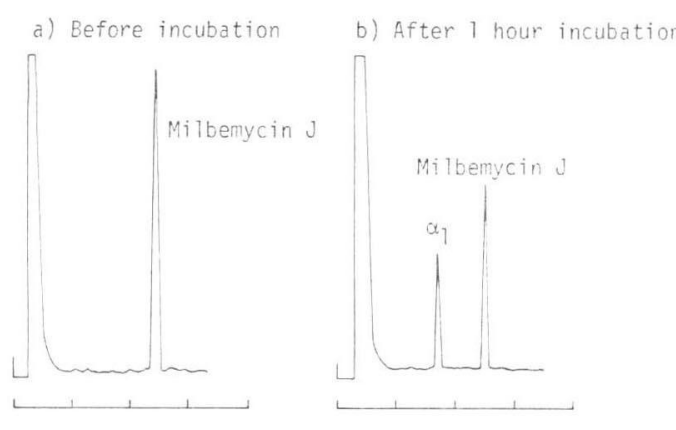

c) Before incubation

d) After 1 hour incubation
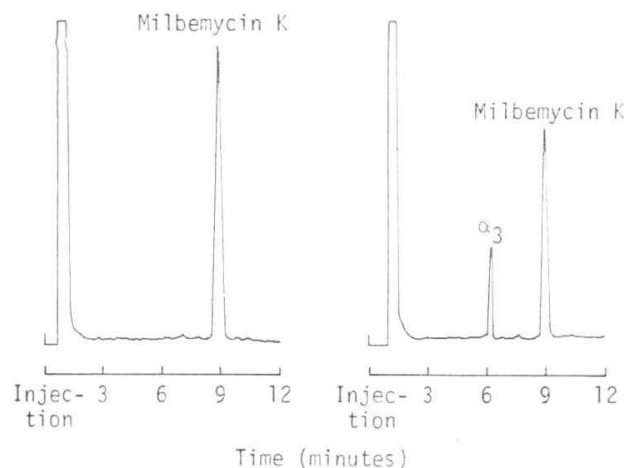

Time (minutes)

$\alpha_{1}$ and $\alpha_{3}$, respectively (Fig. 7). The bioconversion of milbemycins $\mathrm{J}$ and $\mathrm{K}$ to milbemycins $\alpha_{1}$ and $\alpha_{3}$ increased at a linear rate for the first hour (Fig. 8). The optimum $\mathrm{pH}$ of the bioconversion of milbemycins $\mathrm{J}$ and $\mathrm{K}$ to milbemycins $\alpha_{1}$ and $\alpha_{3}$ was 7.0. The effect of cell age on the conversion activities was examined with the intact cells which were harvested during $24 \sim 190$ hours cultivation. Maximal apparent specific activity was observed in 72-hour cultured cells, and relatively high con-
Fig. 8. Time course of the bioconversion of milbemycins $\mathrm{J}$ and $\mathrm{K}$ by the intact cells.

The experimental methods are the same 7 as described in Fig. 7.

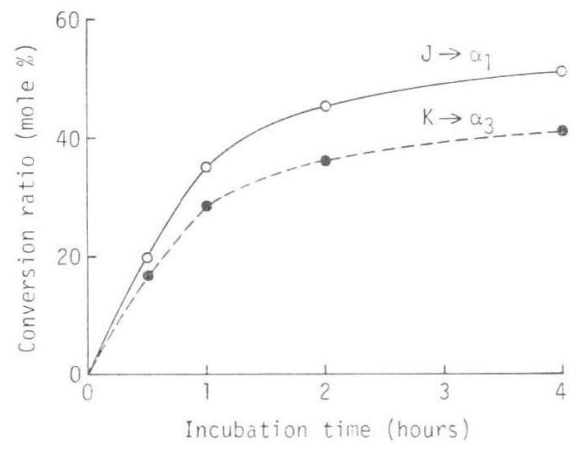

Fig. 9. Structure of milbemycins $\alpha_{1}, \alpha_{3}$, J and K.

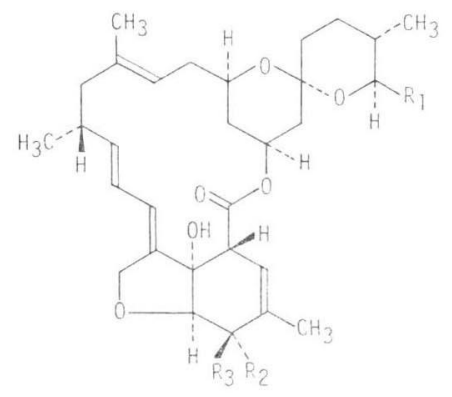

\begin{tabular}{ccccc}
\hline Milbemycin & $\mathrm{R}_{1}$ & $\mathrm{R}_{2}$ & $\mathrm{R}_{3}$ \\
\hline$\alpha_{1}$ & $\mathrm{CH}_{3}$ & $\mathrm{H}$ & & $\mathrm{OH}$ \\
$\alpha_{3}$ & $\mathrm{C}_{2} \mathrm{H}_{5}$ & $\mathrm{H}$ & & $\mathrm{OH}$ \\
$\mathrm{J}$ & $\mathrm{CH}_{3}$ & & $=\mathrm{O}$ & \\
$\mathrm{K}$ & $\mathrm{C}_{2} \mathrm{H}_{5}$ & & $=\mathrm{O}$ & \\
\hline
\end{tabular}

Table 2. Conversion of milbemycins $\mathrm{J}$ and $\mathrm{K}$ to milbemycins $\alpha_{1}$ and $\alpha_{3}$ by crude extracts.

The reaction mixture contained milbemycin $\mathbf{J}$ (0.65 mmole) or milbemycin $\mathrm{K}(0.23 \mathrm{mmole})$ and $0.8 \mathrm{ml}$ of cell free extracts $(4.1 \mathrm{mg}$ protein $/ \mathrm{ml})$ in a total volume of $1 \mathrm{ml}$ of $0.1 \mathrm{M}$ phosphate buffer $(\mathrm{pH}$ 7.0), and was incubated at $28^{\circ} \mathrm{C}$ for 20 hours with shaking.

\begin{tabular}{l|rc}
\hline \multirow{2}{*}{} & \multicolumn{2}{|c}{ Conversion ratio (mole \%) } \\
\cline { 2 - 3 } & $\mathrm{J} \rightarrow \alpha_{1}$ & $\mathrm{~K} \rightarrow \alpha_{3}$ \\
\hline None & 2.7 & Trace \\
+NADH 1 mmole & 37.5 & 33.7 \\
+NADPH 1 mmole & 13.9 & 12.8 \\
\hline
\end{tabular}
SO. 
version activities were maintained during $48 \sim 190$ hours. It was found in the experiments described above that both milbemycin production and milbemycins $\mathrm{J}$ and $\mathrm{K}$ conversion occurred simultaneously. However, the intact cells of strain Rf-107 could not convert milbemycins J and $\mathrm{K}$ to milbemycins $\alpha_{1}$ and $\alpha_{3}$, but accumulated milbemycins $\mathrm{J}$ and $\mathrm{K}$ because of a deficiency of the enzyme related to the conversion.

Milbemycins $\mathrm{J}$ and $\mathrm{K}$ were also converted by the cell free extracts to milbemycins $\alpha_{1}$ and $\alpha_{3}$, respectively (Table 2). In the presence of NADH about $37 \%$ of the added milbemycin $\mathrm{J}$ and $33 \%$ of the added milbemycin $\mathrm{K}$ were converted to milbemycins $\alpha_{1}$ and $\alpha_{3}$, respectively. In the presence of NADPH about $14 \%$ of the added milbemycin $\mathrm{J}$ and $13 \%$ of the added milbemycin $\mathrm{K}$ were converted to milbemycins $\alpha_{1}$ and $\alpha_{3}$, respectively. However, in the absence of both NADH and NADPH only a trace of milbemycins $\mathrm{J}$ and $\mathrm{K}$ were converted to milbemycins $\alpha_{1}$ and $\alpha_{3}$, respectively. The above results suggest that milbemycins $\mathbf{J}$ and $\mathrm{K}$ are precursors of milbemycins $\alpha_{1}$ and $\alpha_{3}$, respectively (Fig. 9).

FURUMAI et $a l .^{6)}$ reported the bioconversion pathway of platenomycins, a family of 16 -membered macrolide antibiotics, in which platenolide I $(\mathrm{C}-9, \mathrm{O}=\mathrm{C} /)$ was converted to platenolide II $(\mathrm{C}-9$, HOĆH) by the washed mycelium of the blocked mutants of Streptomyces platensis subsp. malvinus MCRL 0388. A similar reaction was observed between carbomycin A and maridomycin II or carbomycin B and leucomycin $\mathrm{A}_{3}$ using intact cells or growing cultures of Streptomyces hygroscopicus No. B-5050-HA and its mutants ${ }^{7)}$. MATSUHASHI et al. also reported the interconversion between midecamycin $\mathrm{A}_{1}$ and $\mathrm{A}_{3}$ by the enzyme system extracted from Streptomyces mycarofaciens No. 510-198). Our experimental results agree with the above reports.

\section{References}

1) Takiguchi, Y.; H. Mishima, M. Okuda, M. Terao, A. Aoki \& R. Fukuda: Milbemycins, a new family of macrolide antibiotics: Fermentation, isolation and physico-chemical properties. J. Antibiotics 33: 1120 1127,1980

2) Mishima, H.; M. Kurabayashi, C. Tamura, S. Sato, H. Kuwano, A. Saitoh \& A. Aoki: Structures of milbemycins $\alpha_{1}, \alpha_{2}, \alpha_{3}, \alpha_{4}, \alpha_{5}, \alpha_{8}, \alpha_{7}, \alpha_{8}, \alpha_{9}, \alpha_{10}$ and $\beta_{1}$. Abstract Papers 18 th Symp. Chem. Natural Products, pp. 309 316, Kyoto, Oct. $17 \sim 19,1974$

3) Mishima, H.; M. Kurabayashi, C. Tamura, S. Sato, H. Kuwano \& A. Aoki: Structures of milbemycins $\beta_{1}, \beta_{2}$ and $\beta_{3}$. Tetrahedron Lett. 1975: 711 714, 1975

4) Okazaki, T.; M. Ono, A. Aoki \& R. Fukuda: Milbemycins, a new family of macrolide antibiotics: Producing organism and its mutants. J. Antibiotics 36: 438 441, 1983

5) Takiguchi, Y.; M. Ono, S. Muramatsu, J. Ide, H. Mishima \& M. Terao: Milbemycins, a new family of macrolide antibiotics: Fermentation, isolation and physico-chemical properties of milbemycins D, E, F, G and H. J. Antibiotics 36: 502 508, 1983

6) Furumai, T.; K. TAKeda \& M. Suzuki: Studies on the biosynthesis of basic 16-membered macrolide antibiotics, platenomycins. IV. Biosynthesis of platenomycins. J. Antibiotics 28: 789 797, 1975

7) Suzuki, M.; T. Takamaki, K. Miyagawa, H. Ono, E. Higashide \& M. Uchida: Interconversion among 16-membered macrolide antibiotics belonging to leucomycin-maridomycin group. Agric. Biol. Chem. 43: $1331 \sim 1336,1979$

8) Matsuhashi, Y.; H. Ogawa \& K. Nagaoka: The enzymatic interconversion between midecamycin $\mathrm{A}_{1}$ and $\mathrm{A}_{3}$. J. Antibiotics 32: $777 \sim 779,1979$ 